\title{
PELATIHAN SENI DAUR ULANG KERTAS UNTUK MENCIPTAKAN PELUANG USAHA BAGI ANAK JALANAN DI KECAMATAN DUREN SAWIT JAKARTA TIMUR
}

\author{
Durotul Yatimah \\ Jurusan PLS, Fakultas Ilmu Pendidikan, Universitas Negeri Jakarta,
}

\begin{abstract}
ABSTRAK
Di kota besar seperti DKI Jakarta, dibangun berbagai gedung bertingkat, dengan segala fasilitas pendukungnya. Disi lain, banyak pula perumahan kumuh yang sangat memprihatinkan. Sebanyak 2/3 penduduk di perkampungan kumuh itu adalah anak-anak termasuk anak remaja.

Seringkali dilihat di tempat-tempat keramaian, di perempatan lampu merah atau pun di terminal, anak-anak maupun remaja melakukan aktivitas jalanan. Berbagai cara mereka lakukan untuk mendapatkan penghasilan, misalnya; mengamen, mengelap mobil, atau aktivitas lain yang pada intinya meminta belas kasihan orang untuk sekedar memberikan uang recehan.

Seiring dengan berjalannya waktu, jumlah angkatan kerja yang tidak terserap dunia kerja mengalami peningkatan. Kondisi ini berimplikasi pada semakin bertambah nya jumlah angka pengangguran, jumlah angka anak jalanan dan bertmbah tingginya tingkat kriminalitas di berbagai kota di Indonesia.

Melihat kondisi tersebut, maka dunia pendidikan harus mampu berperan aktif menyusun strategi penanggulangan melalui strategi pengembangan kemampuan hidup (life skill).Salah satu jalur pendidikan adalah Pendidikan Luar Sekolah.

Metodelogi pengabdian pada masyarakat ini dilakukan dengan pemberian teori dan praktek langsung. Hasil pelatihan menunjukan bahwa pengetahuan, sikap dan keterampilan yang ditampilkan peserta pada saat pos test, berbeda dengan hasil pre-test. Hal ini berarti bahwa pelatihan daur ulang kertas ini mampu menjadikan peserta trampil mempraktekan seni daur ulang kertas, dibandingkan sebelumnya yang tidak mengetahui apa-apa mengenai daur ulang kertas bahkan menganggap bahwa kertas bekas itu barang yang menyempitkan ruangan,menimbulkan udara kotor serta menjadi penyebab timbulnya penyakit.Setelah pelatihan, mereka mampu menunjukan bahwa hasil daur ulang kertas itu dapat membuka peluang usaha bagi mereka, mampu menjadikan mereka mandiri dan secara bertahap dapat menambah penghasilan mereka.
\end{abstract}

Kata Kunci : Daur ulang, kertas bekas, anak jalanan

\section{PENDAHULUAN}

Pertumbuhan penduduk Jakarta sangat pesat, kondisi ini menjadikan munculnya perumahan kumuh yang sangat memprihatinkan. Sebanyak 2/3 penduduk di perkampungan kumuh itu adalah anak-anak termasuk anak remaja.Seiring dengan kondisi social ekonomi yang memprihatinkan, anak-anak itu umumnya rentan dengan permasalahan social misalnya menjadi anak jalanan. Jumlah anak jalanan di Kecamatan Duren Sawit relative lebih banyak dibandingkan dengan wilayah kecamatan lainnya di Jakarta Timur

Anak-anak jalanan umumnya rentan dengan perilaku menyimpang, menimbulkan berbagai masalah yang sulit untuk dipecahkan dalam waktu singkat. Disisi lain, anak adalah pilar utama generasi bangsa. Oleh karena itu perlu segera dicarikan solusi yang tepat untuk penyelamatan hidup mereka.Dunia pendidikan harus mampu memberikan bekal keterampilan yang berguna untuk kehidupan mereka. Kementerian Pendidikan Nasional melalui jalur pendidikan luar sekolah berusaha meningkatkan pengetahuan, kepribadian dan keterampilan generasi muda tersebut,,sehingga manusia selalu mendapatkan hal-hal baru didalam kehidupannya. Peningkatan potensi kecakapan hidup tersebut ditujukan untuk meningkatkan berbagai potensi anak, sehingga mereka secara bertahap dapat hidup mandiri dan pada gilirannya mampu membangun 
harkat dan martabat dirinya sebagai makhluk Tuhan.

Permasalahannya tidak semua anak memahami arti penting daur ulang sampah sehingga menjadi barang yang bernilai tinggi secara social ekonomi.Mereka masih memandang sampah sebagai barang yang tidak berguna bahkan menjijikan.Pengabdian pada masyarakat ini, merupakan upaya untuk mengatasi kondisi sebagaimana disebutkan di atas.Kegiatan ini difasilitasi oleh Lembaga Pengabdian Pada Masyarakat Universitas Negeri Jakarta sebagai penyandang dana.

\section{PERUMUSAN MASALAH}

Berdasarkan uraian di atas, perumusan masalah pada pengabdian masyarakat ini adalah: Apakah pelatihan ketrampilan daur ulang sampah dapat menciptakan peluang usaha bagi anak-anak jalanan di Kecamatan Duren Sawit? Secara rinci rumusan masalah pada pengabdian masyarakat ini adalah sebagai berikut :

1. Bagaimanakah pelaksanaan pelatihan daur ulang sampah ?

2. Apakah Pelatihan Daur Ulang sampah dapat meniciptakan peluang usaha bagi anak-anak jalanan di Kecamatan Duren Sawit?

\section{LANDASAN TEORI}

Menurut Edwin B.Flippo yang dikutif oleh Malayu SP.Hasibuan $(2006 ; 70)$ pelatihan adalah "usaha untuk meningkatkan pengetahuan dan keahlian seseorang (karyawan) untuk mengerjakan suatu pekerjaan tertentu. Malayu SP.Hasibuan (2006;70) berdasarkan pendapat Andrew F.Sikula mengatakan bahwa "Pelatihan adalah proses pendidikan jangka pendek dengan menggunakan prosedur yang sistematis dan terorganisir, sehingga tenaga kerja belajar pengetahuan tehnik pengerjaan dan keahlian untuk tujuan tertentu".

Menurut Peters, pelatihan dilakukan pada saat (1) ada beberapa model penampilan kerja yang khusus yang perlu dikembangkan, (2) Diperlukan praktek untuk mengembangkan penampilan kerja itu, (3) Upaya untuk mencapai hal itu dilakukan secara mudah dan dapat dimengerti. Pelatihan diberikan dengan alas an karena adanya teknologi baru didalam pekerjaan, atau mungkin juga sebagai upaya pengenalan atau sosialisasi berbagai hal dalam organisasi pada para pegawai baru.

Pelatihan diberikan karena adanya jenis keterampilan hidup (life skills) yang dapat dilatihkan kepada anak-anak jalanan.Melalui pemberian latihan itu diharapkan anak-anak jalanan memiliki bekal keterampilan yang berguna sebagai bekal peluang usaha.

\section{A. Pendidikan Kecakapan Hidup (Life Skill)}

Kecakapan hidup menurut Brolling (BPPLS, 2008) adalah interaksi berbagaipengetahuan dan kecakapan yang sangat penting dimiliki seseorang sehingga mereka mandiri. Brolling selanjutnya mengatakan (BPPLS,2008). Kecakapan hidup ini dapat dikelompokan menjadi tiga bagian, yaitu : (1) Kecakapan hidup sehari-hari atau daily living skill (2) Kecakapan bidang pribadi dan social atau personal and social skill), (3) Kecakapan hidup bekerja (atay Occupational Skill)

Kecakapan hidup menurut WHO (1987) adalah "berbagai kemampuan untuk dapat beradaptasi dan berperilaku positif, yang memungkinkan seseorang mampu menghadapi berbagai tantangan dalam hidupnya sehari-hari Secara efektif WHO membagi kecakapan hidup menjadi 5 kecakapan, yakni :

1) Kecakapan mengenai diri (self awareness) atau kecakapan pribadi (personal skill)

2) Kecakapan social (social skill)

3) Kecakapan berfikir (thinking skill)

4) Kecakapan akademik (academic skill). Sasaran life skill menurut Unesco (2007:25) adalah mereka yang tidak mendapatkan peluang mengikuti pendidikan, terutama anak-anak yang putus sekolah, serta remaja, pemuda,dan orang dewasa yang tidak memiliki keterampilan sama sekali. Sasaran pelatihan keterampilan seni daur ulang sampah adalah anak-anak jalanan.Apabila anak-anak jalanan telah memiliki keterampilan melakukan daur ulang kertas, tinggal melanjutkannya pada bagaimana melakukan 
rintisan usaha. Merintis usaha berarti melakukan langkah memulai usaha secara mandiri, secara bertahap mereka diharapkan dapat memanfaatkan sarana yang ada untuk merintis usaha tersebut.

\section{B. Hakekat Anak Jalanan}

Anak jalanan merupakan anak yang umumnya sering berada di jalanan, baik di perempatan lampu merah maupun di tengah pusat keramaian kota lainnya, seperti di stasiun kereta api dan terminal, untuk mencari nafkah dengan cara mengamen, mengelap mobil, dan lain-lain. Sehubungan dengan itu, anak jalanan sering dicap sebagai pengganggu ketertiban umum.

UU Perlindungan anak No.23 tahun 2003 menyatakan bahwa anak jalanan merupakan anak-anak yang berumur dibawah 16 tahun yang sudah melepaskan diri dari keluarga dan lingkungan masyarakat terdekat dan larut dalam kehidupan yang berpindahpindah di jalan raya.

Dalam kehidupan keseharian, anak jalanan ini memiliki permasalahan sebagai berikut :

1. Masalah pribadi, yang berhubungan dengan situasi di rumah, pertemuan, kondisi fisik, penampilan, emosi, penyesuaian social, tugas dan nilai-nilai.

2. Masalah khas remaja umumnya, yaitu pribadi yang belum mantap karena berada pada usia antara anak dan usia dewasa muda. Masalah-masalah itu misalnya : kemandirian, kesalah pahaman atau penilaian berdasarkan stereotip yang keliru, adanya hak-hak yang lebih besar dan lebih sedikit kewajiban dibebankan oleh orang tua.

Seiring dengan sebutan remaja adalah pilar utama generasi bangsa di masa depan, maka menjadi sebuah kebutuhan yang tak terelakan untuk mencari solusi yang tepat demi penyelamatan hidup anak-anak jalanan agar mereka menjadi generasi muda harapan bangsa.

\section{Pelatihan Seni Daur Ulang Sampah}

Pelatihan seni daur ulang sampah adalah kegiatan mengolah sampah yang secara selintas tidak ada manfaatnya. Pelatihan Seni Daur Ulang Sampah ini dipilih atas pertimbangan bahwa anak-anak jalanan di Kelurahan Klender kebanyakan anak laki-laki usia remaja. Memberikan pengetahuan dan keterampilan hidup berbentuk Seni Daur Ulang Sampah pada remaja, berarti turut mendukung suksesnya program pembinaanpemuda yang secara langsung atau tidak langsung turut pula mendorong suksesnya program pembinaan generasi muda.

\section{METODELOGI, HASIL PENGABDIAN PADA MASYARAKAT DAN PEMBAHASAN}

Metode pengabdian pada masyarakat ini adalah pemberian teori dan praktek langsung mengenai pengetahuan dan keterampilan hidup berbentuk Seni Daur Ulang Sampah. Hasil pre tes menunjukan bahwa mereka tidak tahu bahwa sampah apabila diolah dapat jadi barang berguna. Mereka memandang bahwa sampah itu tidak ada manfaatnya dan bahkan mengotori ruang dan menimbulkan udara/ aroma tidak nyaman.Mereka tidak tahu bagaimana membuat daur ulang sampah. Mereka menyadari pentingnya skill/ keterampilan untuk melakukan daur ulang sampah, sehingga benar-benar dapat memanfaatkan kembali sampah tersebut.Dan dapat menjadi sumber penghasilan.

Setelah peserta selesai melakukan pelatihan khususnya setelah praktek keterampilan seni daur ulang sampah, kemudian dilakukan tes.Hasil tes menunjukan nilai yang cukup baik.Peserta pelatihan trampil mempraktekan seni daur ulang sampah.Mereka mampu menunjukan bahwa hasil daur ulang sampah itu mampu menjadi kompos yang berguna untuk tanaman.Keterampilan mereka dalam melakukan seni daur ulang sampah tersebut, mampu memberi nilai tambah untuk hidup mereka.Kompos yang dihasilkan dari daur ulang sampah mampu memnjadi benda yang bernilai ekonomi cukup tinggi, dan mampu menjadi sebuah peluang bisnis yang menjanjikan.Setelah melakukan daur ulang kertas tersebut, masyarakat pun mulai sadar bahwa kegiatan daur ulang sampah tersebut, telah turut mendukung kampanye "go green" yang saat ini sedang gencar digalakan oleh berbagai kalangan.Meski pun masih dalam tahap pemikiran yang sederhana, peserta pelatihan memahami bahwa "go green" itu dapat membuat bumi kita lebih "hijau" atau lebih bersih.Pelatihan keterampilan seni daur ulang sampah, menjadikan peserta lebih perduli terhadap lingkungan sekitar. 
Melalui pelatihan ini, diharapkan masyarakat Klender, khususnya peserta pelatihan daur ulang sampah dapat meningkat skillnya dan sekaligus secara bertahap memiliki taraf kehidupan yang meningkat, secara social ekonomi.

Nara sumber kegiatan ini adalah pelaksana kegiatan yang didampingi 1 orang instruktur dan 1 orang mahasiswa. Instruktur, mahasiswa pendamping, maupun para peserta pelatihan sangat bersemangat dalam seluruh kegiatan ini, baik dalam proses pembahasan materi, maupun dalam melakukan praktek keterampilan.

\section{DAFTAR PUSTAKA}

[1] Albert Wijaya, 2008, Budaya Politik dan Pembangunan Ekonomi. Jakarta. LP3ES

[2] Becker G.S. 2006. Human Capital, A theoritical and Empirical Analysis with Speccial reference to Education. Chicago, University of Chicago Press

[3] Benghart W, Frank, (2008), Educational Planning, The Mac Millan Company, New York.

[4] Coombs, P. (1968). The World Educational Crisis, New York: Oxford University Press.

[5] David E. Rye. (2005). Tolls for Executives: The Vest Pocket Entrepreneur. Terjemahan. Prentice Hall, Inc. Englewood Cliffs, New Jersey.

[6] Drucker, FF. (2006), Inovasi dan Kewirausahaan, Praktek dan Dasardasar, Jakarta, Erlangga.
[7] Hatton, Michael J, (1997), Lifelong learning; Policies, Practices, and Programs, APEC Publication, Canada.

[8] Kaple, SN; ( ); Change For Children; Ideas and Activities for Individualizing learning, Goodyear Publishing Compani, Inc. California.

[9] Kusumah, Inu Hardi dkk (2004); Quo Vadis Pendidikan Sepanjang Hayat dan dan Belajar Sepanjang Hayat, Makalah, PLS S2, UPI Bandung.

[10] Peraturan Pemerintah Nomor 73 Tahun 1991 tentang Penyelenggaraan Pendidikan Nasional

[11] Sudjana, Djudju (2004); Manajemen program Pendidikan; Fallah Production, Bandung

[12] Sudjana, Djudju, (2004); Pendidikan Non Formal, Fallah Production, Bandung

[13] Trisnamansyah, S, (2007), Pendidikan Sekolah Dan Luar Sekolah. Dalam Natawidjaya, R., Sukmadinata, N.S., Ibrahim, R., Djohar, A (Penyunting). Rujukan Filsafat, Teori, dan Praksis Ilmu Pendidikan. Bandung: Universitas Pendidikan Indonesia Press ( Halaman 281-282)..

[14] Sriwahyuningsih, http//www.depsos. go.id/Balitbang/Puslitbang/2UKS/ executive, Desember 2008

[15] Zaltman, G. (1972). Creating Social Change, Holt. New York.: Rinehart and Winston Inc. 